\title{
医療用金属材料としてのジルコニウムの耐食性
}

\author{
堤 祐介* \\ * 東京医科歯科大学 生体材料工学研究所 \\ 医療基盤材料研究部門 金属生体材料学分野

\section{Corrosion Resistance of $\mathrm{Zr}$ as Metallic Biomaterials} \\ Yusuke Tsutsumi * \\ * Associate Professor, Tokyo Medical and Dental University
}

\begin{abstract}
The corrosion behavior of $\mathrm{Zr}$ and $\mathrm{Zr}$-based binary alloys $(\mathrm{Zr}-\mathrm{Ti}, \mathrm{Zr}-\mathrm{Nb}, \mathrm{Zr}-\mathrm{Ta}, \mathrm{Zr}-\mathrm{Pd}, \mathrm{Zr}-\mathrm{Pt}, \mathrm{Zr}-\mathrm{Cu}$, and $\mathrm{Zr}-$ $\mathrm{Au}$ ) with various concentrations in simulated body fluids were investigated. Pure $\mathrm{Zr}$ showed pitting corrosion during the potentiodynamic anodic polarization measurement in Hanks' solution, however, the pitting potential of $\mathrm{Zr}$ was much higher than that of type $316 \mathrm{~L}$ stainless steel. The pitting potential was widely changed by the composition of the alloy. In particular, $\mathrm{Zr}$ alloyed with larger amount of $\mathrm{Ti}, \mathrm{Nb}$, and $\mathrm{Au}$ showed higher pitting potential than pure Zr. Thus, these alloying elements can be considered as beneficial for improving corrosion resistance in physiological environment. On the other hand, $\mathrm{Zr}-\mathrm{Cu}$ alloys showed low pitting potentials. Therefore, $\mathrm{Zr}$ alloys should be carefully designed when they will be used in chloride-containing environments.
\end{abstract}

Key words : zirconium, pitting corrosion, biomaterial, alloying, simulated body fluid

\section{1.は じめに}

\section{1 生体材料における金属の役割}

高齢化社会, 高齢社会から超高齢社会へ突入した現代 社会において，医療における材料への期待は高まってお り, 現場からの多くの要求に応えるために, さまざまな 特性を有する新たな生体材料開発の研究が進められてい る.

生体材料は一般材料と同様に，金属材料，高分子材料, セラミック材料の 3 種類に分類され，それぞれの特性を 生かして各医療デバイスに用いられている.なかでも金 属材料は, 高強度と高延性のバランスによる優れた機械 的性質を示すため, 使用中に荷重のかかる，骨折部内固 定材, 人工関節，歯科材料などのデバイスに主に用いら れている．体内埋入型のデバイスに限定すれば，金属材 料はその約 8 割を占めるほど, 現在医療において無くて はならない存在となっている。

\section{2 医療用金属の種類とその耐食性}

これまでに医療用に使用されてきた金属材料は，貴金 属合金，ステンレス鋼，コバルトクロム $(\mathrm{Co}-\mathrm{Cr})$ 合金, 純チタン（Ti）および $\mathrm{Ti}$ 合金が主となっている。いず れも熱力学的に安定な元素で構成されているか, もしく は安定な不働態を示すため, 耐食性は非常に高いと一般 的に認識されている金属である。一方，生体内で長期間 使用されるこれらの金属材料にとって，耐食性とは材料 の寿命ではなく，生体への悪影響が無いことを保証する ための性質と捉えなければならない，腐食反応により体 内に金属イオンが放出されると，たとえわずかであって も毒性やアレルギー性を示す場合がある．各金属イオン

* 干 101-0062 東京都千代田区神田駿河台 2-3-10 (2-3-10 KandaSurugadai, Chiyoda-ku, Tokyo, 101-0062 Japan)
のもつ毒性は大きく異なっているが，周期表とある程度 の相関が認められている。例えば，第 12 族のカドミウ 厶 $(\mathrm{Cd})$, 水銀 $(\mathrm{Hg})$ などは強い毒性を示すが，第 4 族

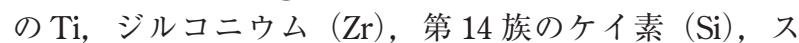
ズ $(\mathrm{Sn})$ などは毒性が低い傾向にある。また，第 5 族の バナジウム $(\mathrm{V})$, 第 11 族の銅 $(\mathrm{Cu})$ ように, 原子量の 小さい金属は毒性を示すが, ニオブ $(\mathrm{Nb})$, タンタル $(\mathrm{Ta})$, 金 $(\mathrm{Au})$ のように, 同族内で原子量の大きい金 属は細胞毒性を示さない場合もある11).

今後の医療用金属材料の開発にあたっては，材料の耐 食性が十分に高いことだけではなく，材料を構成する元 素自体の毒性が低いものであることが求められるため, 合金設計時において選択できる元素に大きな制約がある ことがわかる.

\section{3 チタンとジルコニウム}

前節で紹介した医療用金属材料の中でも，Ti は比重が 4.5 と小さく比強度に優れ, 標準電極電位が- $1.63 \mathrm{~V}_{\mathrm{SHE}}$ と活性な金属であるにもかかわらず，非常に安定な不働 態皮膜を形成するためステンレス鋼以上の耐食性を示 す．Ti は細胞毒性もほとんど示さず，骨との親和性が高 く，長期間の体内埋入後に骨と癒合する特有の性質を示 すことから，歯科インプラントや人工関節といった，骨 と接触して用いられるデバイスに主に用いられてきた. しかし，髄内釷や骨固定材のスクリューなど，治癒後に 体内から抜去するケースのあるデバイスおいては，Ti 合 金と骨との親和性が仇となり，抜去手術中に再骨折を起 こす例が報告されている ${ }^{2), 3)}$. このため, 抜去を前提と した場合には，骨形成能に劣るステンレス鋼が使用され るが，ステンレス鋼はTiよりも耐食性に劣ることから， $\mathrm{Ti}$ と同等の機械的性質・耐食性を示す一方で，仮骨を形 成しない材料開発が求められている.

一方，近年になって磁気共鳴撮像（MRI）による診断 が急速に普及してきたが，印加磁場によって金属製デバ 
イスが磁化され，MR画像の欠損やゆがみ（アーチファ クト）が生じ周囲組織の診断を妨げることが問題となっ ている.アーチファクトの大きさは材料の磁化率に依存 するため，これを縮小するためには金属材料の磁化率を 低減させる必要があり, MRI 対応の低磁化率材料の開発 が求められている.

周期表で $\mathrm{Ti}$ と同じく第 4 族に属する $\mathrm{Zr}$ は，多くの物 理的・化学的性質で $\mathrm{Ti}$ と類似した性質を示す. $\mathrm{Zr}$ は $\mathrm{Ti}$ と同様，熱力学的には活性な金属であるが，表面に不働 態皮膜を形成するため耐食性に優れるだけでなく，人体 に対してほとんど毒性を示さず，生体材料としても十分 なポテンシャルを有している，Tiにみられる骨癒合の要 因となっているのは, 生体内中で自発的にリン酸カルシ ウムをその表面に形成することが知られているが，Zrで はこのリン酸カルシウム形成が起こらないため, 骨癒合 を抑制する効果が期待される ${ }^{4)}$ 。また， Zr の磁化率は Ti の $1 / 2$, 医療用に主に用いられるステンレス鋼 (SUS316L) の $1 / 30$ と低い值を示す ${ }^{5)}$. これらのことから, Zr は上 記の問題を解決できる新たな医療用金属材料として有望 視されている.

\section{4 生体材料としての $\mathrm{Zr}$ の耐食性}

Zr はこれまでに化学プラントや原子炬材料として主に 用いられてきた材料であり，酸やアルカリに対する耐食 性が高い一方，塩化物に対する局部腐食感受性をもつた め, 塩化物に曝される環境においては局部腐食発生のリ スクをもつことが知られている。しかしながら， $\mathrm{Zr}$ の塩 化物イオン環境中における耐食性についての詳細な報告 はほとんどなく，知見が不足している．生体内環境には 約 $0.14 \mathrm{molL}^{-1}$ の塩化物イオンが必ず存在し, 体液循環 によってその濃度がほぼ一定に保たれているため，実用 時における塩化物イオン溶液との接触は避けられず，ま た，防食のためにインヒビターを添加するといった，環 境サイドをコントロールする防食技術の適用は不可能で ある。したがって, $\mathrm{Zr}$ の生体材料への応用にあたって は, 生体内環境のように, 塩化物イオンが存在する環境 における耐食性を, 詳細なレベルまで把握することが必 要である.

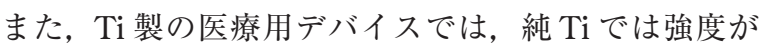
不足となる場合, Ti-6Al-4V 合金や Ti-6Al-7Nb 合金が 用いられるが，Zr を医療用デバイスに応用するにあたっ ては, Ti と同様に，合金化して用いられることが想定さ れる. $\mathrm{Zr}$ と同じく塩化物イオンに対する局部腐食感受性 をもつステンレス鋼は, 合金元素とその濃度の組み合わ せにより，耐食性が著しく変化することが知られており， Zr においても同じであることが考えられる.

そこで本稿では，生体内環境を模擬した擬似体液中に おける純 $\mathrm{Zr}$ の基本的な耐食性に加え，いくつかの $\mathrm{Zr}$ 合 金を作製し，耐食性がどのように変化するかを調査した 結果を紹介する。

\section{2. 耐食性評価法}

本研究での $\mathrm{Zr}$ および $\mathrm{Zr}$ 合金に対する耐食性評価に用 いる溶液として，擬似体液のひとつであり細胞外液の組 成を模擬した Hanks 液（グルコース不含）を選定した. Hanks 液の組成を表 1 に示す. Hanks 液は塩化物イオン を含み,リン酸と炭酸による $\mathrm{pH} 7.4$ の緩衝液である。生 体内環境での溶存酸素の濃度は大気開放条件のおよそ1

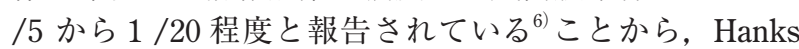
液の $\mathrm{pH}$ を変化させずに溶存酸素濃度を大気開放条件の $1 / 5$ とするため, $\mathrm{N}_{2}-4 \% \mathrm{O}_{2}-0.5 \% \mathrm{CO}_{2}$ 混合ガスを用意 し，試験前に十分な時間曝気を行った。試験温度は 310Kとした。

試料の作製方法を次に示す。スポンジ $\mathrm{Zr}$ (99.6\%) に 対して Ti $(99.5 \%)$, 白金 $(\mathrm{Pt}, 99.9 \%)$, パラジウム (Pd, $99.9 \%), \mathrm{Au}(99.99 \%), \mathrm{Cu}(99.9 \%), \mathrm{Nb}(99.9$ \%)，および Ta (99.95\%）のうちのいずれかを所定の割 合で混合し, 真空アーク溶解炉を用いて約 $30 \mathrm{~g}$ のインゴ ットを溶製した。均一に混合するため, 炉内で溶解と反 転を 10 回以上繰り返した. このインゴットを石英ガラ 又管に真空封入後， $\beta$ 変態点以上の温度から水水中急冷 を施した後, $\beta$ 変態点以下の温度まで再加熱し, 炉冷を 行った. 熱処理後の試料を厚さ約 $1 \mathrm{~mm}$ 間隔に切断し, その断面に耐水研磨紙抏よび湿式バフで研磨を施した。 $0.04 \mu \mathrm{m}$ の $\mathrm{SiO}_{2}$ による研磨を最終条件とし，鏡面仕上げ とした。

Zr 合金の耐食性の評価として，動電位アノード分極試 験（JIS T0302）を行った。対極に白金黒化処理を施した $\mathrm{Pt}$ 電極，参照極に飽和カロメル電極（SCE）を用いた。 作用極には試料表面の一部のみが溶液と接触する構造の PTFE 製ホルダーを用いた ${ }^{7)}$ 。試料の露出面積は 0.353 $\mathrm{cm}^{2}$ （直径 $0.670 \mathrm{~cm}$ ） とした。各電極をポテンショスタ ットに接続し, 開回路で試験液に $10 \mathrm{~min}$ 浸漬した後の 電位を腐食電位 $\left(E_{\text {corr }}\right)$ とし, アナログ接続したファン クションジェネレーターの制御により， $E_{\text {corr }}$ より $20 \mathrm{mV}$ 低い電位を初期電位, $2 \mathrm{~V}$ または $3 \mathrm{~V}$ を限電位として, $+20 \mathrm{mV} \min ^{-1}$ の定速度で電位走査を行った。

\section{3. 実験結果および考察}

\section{1 純 Zr の腐食挙動}

Hanks 液中における純 Zr のアノード分極曲線を図 1 に示す。また，比較材として同条件で試験を行った純 $\mathrm{Ti}$ の結果を図中灰色線で示す。Ti は $2 \mathrm{~V}$ まで分極試験を行 っても，一時的な電流の上昇がみられたものの，安定成 長段階に至る孔食の発生は認められず, 不働態を示す 1 $\mu \mathrm{A} \mathrm{cm}^{-2}$ 程度の低い電流密度を維持したことから, 塩 化物に対する局部腐食感受性をほとんどもたないことが わかる，一方，純 $\mathrm{Zr}$ では約 $1.1 \mathrm{~V}$ で不安定な電流の増減 がみられ, その後 $1.4 \mathrm{~V}$ で急激に電流が増加し, 試料表

表 1 Hanks 液の成分 $\left(\mathrm{mmol} \mathrm{L}^{-1}\right)$

\begin{tabular}{cccccccc}
\hline $\mathrm{Na}^{+}$ & $\mathrm{K}^{+}$ & $\mathrm{Mg}^{2+}$ & $\mathrm{Ca}^{2+}$ & $\mathrm{Cl}$ & $\mathrm{HPO}_{4}{ }^{2-}$ & $\mathrm{SO}_{4}{ }^{2-}$ & $\mathrm{CO}_{3}{ }^{2-}$ \\
\hline 142 & 5.81 & 0.811 & 1.26 & 145 & 0.778 & 0.811 & 4.17 \\
\hline
\end{tabular}




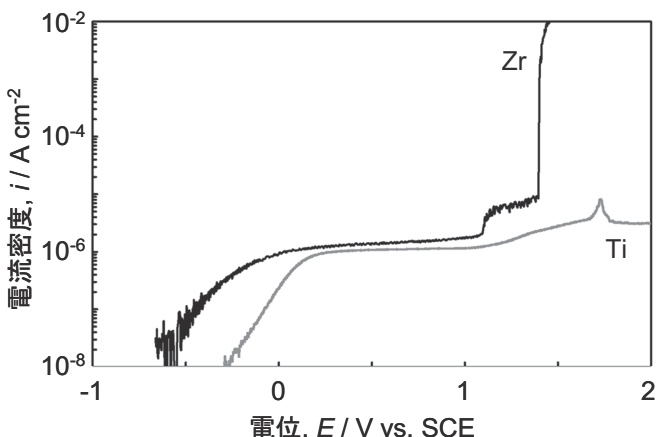

図 1 Hanks 液中におけるチタンとジルコニウムの分極曲線

面には濃い紫色の腐食生成物が観察された。試験後の試 料表面には，局所的な腐食孔が複数存在していたことか ら， $\mathrm{Zr}$ 表面において孔食が起きていたことが確認され た。したがって，純 $\mathrm{Zr}$ は塩化物に対する局部腐食感受 性をもち，局部腐食発生のリスクの面では Tiに劣るこ とがわかった。ただし，同一条件で分極試験を行った医 療用金属材料のステンレス鋼 (SUS316L) や $\mathrm{Ti}-\mathrm{Ni}$ 超弾 性合金（Ti-50.8at\% Ni）の孔食電位 $\left(E_{\mathrm{pit}}\right)$ はそれぞれ $0.2 \mathrm{~V} ， 0.5 \mathrm{~V}$ 程度であったことから，1.1〜 $1.5 \mathrm{~V}$ を示し た純 $\mathrm{Zr}$ の耐局部腐食性はこれらの医療用金属材料と比 較して十分に高いと言える。

動電位アノード分極試験では，局部腐 食発生への抵抗，すなわち不働態皮膜の 安定性に関する有益な情報は得られて も，不働態が維持された状態におけるご くわずかな金属イオンの溶出の程度に関 する判断が難しい，そこで，一定期間， 腐食試験溶液中に単純浸漬を行った後に 溶出金属イオン濃度を測定する試験（JIS T0304）を行った，加速腐食試験液とし て，1mass \%の乳酸（pH2.3）を用い, 310K の温度で純 $\mathrm{Zr}$ および純 Ti $7 \mathrm{~d}$ 浸 漬し, 溶液中に放出された $\mathrm{Zr}, \mathrm{Ti}$ イオ ンの濃度をICP-AESにより分析した結 果を図 2 に示す。アノード分極試験の傾 向とは異なり, 純 Zr からのイオン溶出 は純 Ti と比較して非常に少ないことが わかる，同じ溶液中でのアノード分極試 験では, Ti と Zr のいずれも，少なくと も $2 \mathrm{~V}$ まで不働態を保持していたことか ら, 図 2 の溶出量は不働態皮膜の保護性 の違いを意味しており，Zr は $\mathrm{Ti}$ より優 れることを示す結果であることがわか る。すなわち, $\mathrm{Zr}$ の不働態皮膜の保護 性は非常に高く, 生体中では金属イオン 溶出がほとんど起こらないことを示唆し ている。

これらの結果から， Zr と $\mathrm{Ti}$ の耐食性 は，ともに不㗢態化により担保されてい るが, その腐食挙動は異なっており，塩 化物イオンに対する局部腐食感受性の面 では Tiの方が，不働態皮膜の保護性に よる金属イオン溶出の面では $\mathrm{Zr}$ が優れ

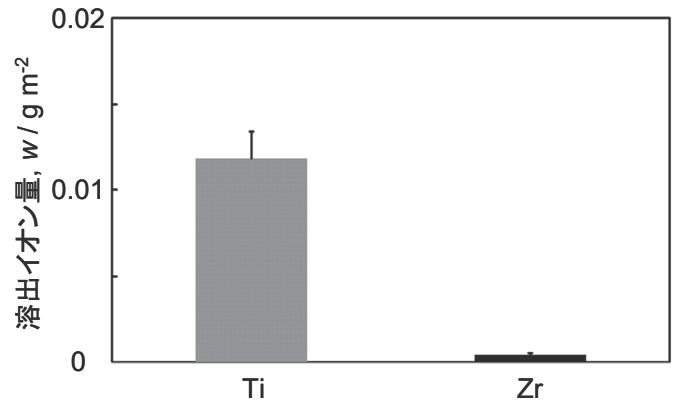

図 2 1mass\%乳酸に $7 \mathrm{~d}$ 浸漬したチタンとジルコニウムのイオ ン溶出

ていることがわかる．生体材料としての純 Zr は，既存 の医療用金属材料であるステンレス鋼や Ti 合金より高 い $E_{\mathrm{pit}}$ を示し，金属イオン溶出も Tiよりはるかに少ない ことから，生体安全性は十分に高いといえる。しかしな がら， $E_{\mathrm{pit}}$ は合金化により容易に変動することが予想さ れるため, 次節ではその傾向について調べた結果を示す。

\section{$3.2 \mathrm{Zr}$ 二元合金の腐食挙動}

$\mathrm{Zr}$ と $\mathrm{Ti}, \mathrm{Nb}, \mathrm{Ta}, \mathrm{Pd}, \mathrm{Pt}, \mathrm{Cu}, \mathrm{Au}$ のいずれかの二 元合金を用いて 3.1 節と同様にアノード分極試験を行い,
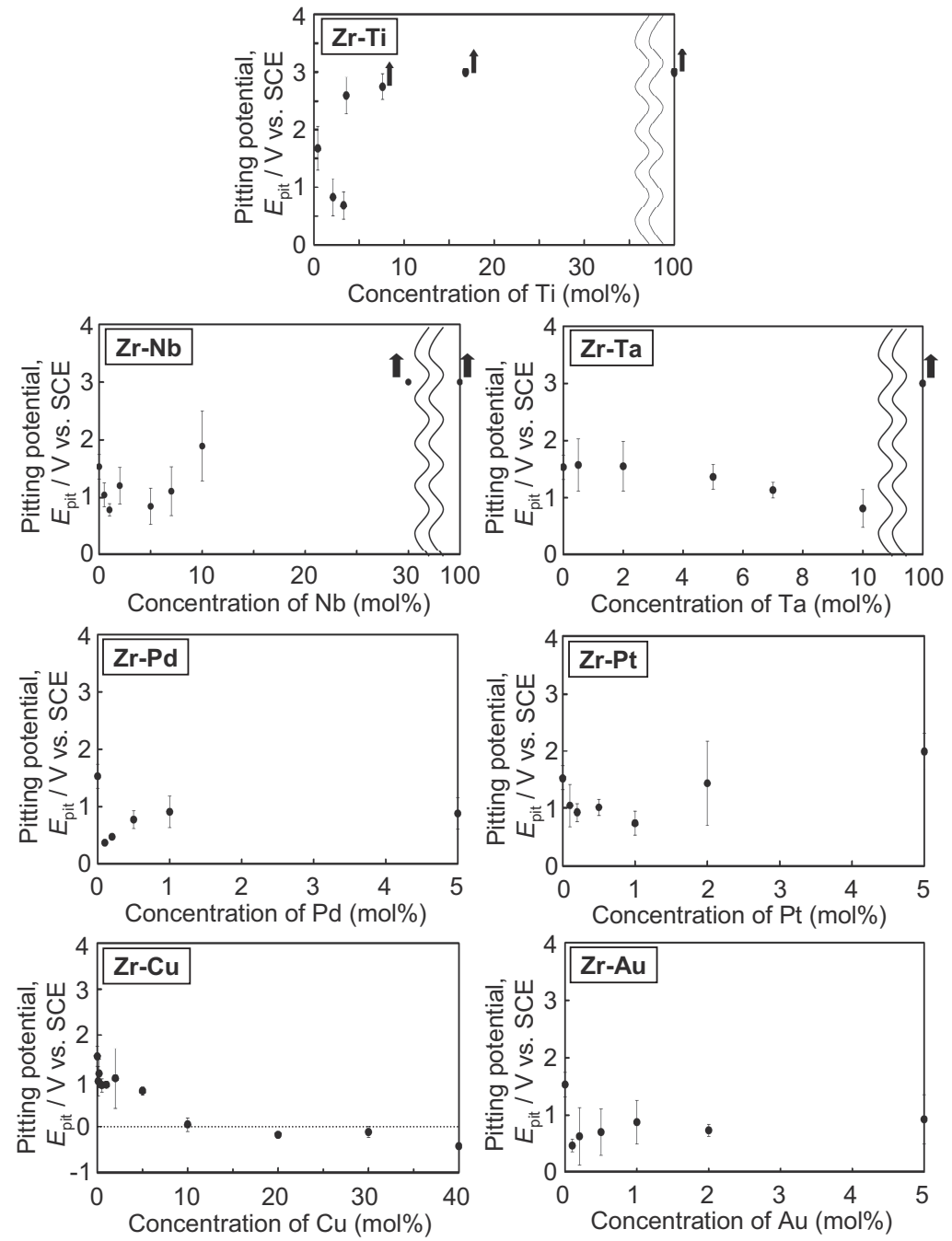

図 3 Hanks 溶液中における $\mathrm{Zr}-\mathrm{X}$ 二元合金の孔食電位 
分極曲線から得られた $E_{\mathrm{pit}}$ の值をまとめたものを図 3 に 示す。いずれも同じ条件で 3 回以上の繰り返し測定を行 い, 平均值と標準偏差をプロットしている. 図中に記載 した上向きの矢印は, 実験の上限電位に設定した $3 \mathrm{~V}$ ま で不働態を保持し, 孔食がみられなかった測定が少なく とも 1 回は含まれているデー夕を表しており，実際の $E_{\text {pit }}$ の值はプロットより高い位置にあることを意味して いる.

純 $\mathrm{Ti}$ ，純 $\mathrm{Nb}$ ，純 $\mathrm{Ta}$ （図中右端のプロット）では $3 \mathrm{~V}$ の上限電位まで孔食が起こらなかったため, $\mathrm{Zr}$ とこれら の元素との合金は，高い $E_{\text {pit }}$ を示すことが予想されたが, 実際には，合金元素の濃度の増加とともに， $E_{\text {pit }}$ は一度 下降した後に上昇に転ずることがわかった。また，その 度合いは元素により異なっており, Ti では $5 \mathrm{~mol} \%$ 以上, $\mathrm{Nb}$ は $10 \mathrm{~mol} \%$ 以上で純 $\mathrm{Zr}$ を上回る $E_{\mathrm{pit}}$ を示し, 耐食性 の向上に効果があることが認められたが，Taでは本実 験の上限濃度である $10 \mathrm{~mol} \%$ まではこのような効果は認 められなかった。

貴金属である $\mathrm{Pd}, \mathrm{Pt}, \mathrm{Au}$ との合金化では, 少なくと も $1 \mathrm{~mol} \%$ までの低濃度の範囲においては $E_{\mathrm{pit}}$ の上昇はみ られなかったが, $5 \mathrm{~mol} \%$ の $\mathrm{Pt}$ では純 $\mathrm{Zr}$ よりも高い $E_{\mathrm{pit}}$ を示し, また, 不働態保持電流密度も大幅に減少してい たことから，条件によっては耐食性の向上に効果がある ことが示唆された。

$\mathrm{Cu}$ との合金化では, $\mathrm{Cu}$ 濃度の上昇とともに $E_{\mathrm{pit}}$ は下 降する傾向を示した，とくに，10 $\mathrm{mol} \%$ 以上の $\mathrm{Cu}$ 濃度 で $E_{\mathrm{pit}}$ はいずれも $0 \mathrm{~V}$ を回っており， $E_{\text {corr }}$ とほとんど 変わらない值となったため, 不働態域が狭く, 容易に腐 食を生じるほど耐食性が低下することを示す結果となっ た，試験後の試料表面は銅の金属色で粗い凹凸形状を呈 しており，全面にわたって脱合金化が進行していたこと が示唆された。したがって, 合金中の $\mathrm{Cu}$ は, $\mathrm{Zr}$ の不働 態化を阻害し, 耐食性を大幅に悪化させることが示され た.

以上のことから, $\mathrm{Zr}$ の耐食性は合金化により大幅に変 化し，合金元素の種類やその濃度に大きな影響を受ける ことがわかる．本稿で紹介した結果は，いずれも均質化 のための熱处理を施した試料についてのものであるが, 実際には，これらの合金の耐食性は熱処理条件にも影響 を受けることが，筆者のこれまでの研究で明らかになっ ている. 例えば, 鋳造まま材の $E_{\mathrm{pit}}$ は, 均質化熱处理材 のそれと比較して $\mathrm{Zr}-\mathrm{Ti}$ の場合は低 ${ }^{8}{ }^{8}, \mathrm{Zr}-\mathrm{Pt}$ の場合は 高くなる ${ }^{9}$ 傾向を示しており，単純に合金組成だけで耐 食性が決定されるわけではないことを表している。すな わち, $\mathrm{Zr}$ の食発生は, 金属組織や相構成, 介在物や久 陥などの存在が複雑に関与した現象であることを意味し ている.

本研究では, これらの合金の孔食発生機構を明らかに
するまでには至っていないが，現在， Sn, Cr，Moなど 他の元素との合金についてもデータの蓄積を行っている ほか, 微小領域に扔ける分極試験により, 孔食発生の起 点となる因子を解明すべく，研究を継続している．塩化 物環境中に扔ける $\mathrm{Zr}$ の腐食機構を究明することは，医 療用だけでなく一般工業用として $\mathrm{Zr}$ の用途を拡大して いくためにも，今後大きく期待されるものと考えている.

\section{4. を と め}

新たな医療用金属材料として期待されるジルコニウム (Zr) およびその合金について, 塩化物環境中における 耐食性を評価した結果, 以下の知見が得られた。

・純 Zr は塩化物に対する局部腐食感受性を示すが，そ の程度は医療用ステンレス鋼（316L）より小さく，医 療用金属材料として十分な耐食性を有している.

- 純 $\mathrm{Zr}$ の不働態皮膜の保護性は純 $\mathrm{Ti}$ より高く, 不働態 皮膜を通じた金属イオンの溶出はほとんど起こらな い.

- Zr 合金の孔食電位は，合金元素の種類や濃度に影響を 受け大きく変化するため, 塩化物環境で用いるための $\mathrm{Zr}$ 合金を設計するにあたっては，機械的性質だけでは なく，耐食性について十分に考慮する必要がある。

\section{謝辞}

本研究にご協力いただいた芝浦工業大学 野田和彦教 授, 下条雅幸教授, 高野陽如氏 (現: 京セラメディカル), 東北大学 原 信義教授, 武藤 泉教授, 菅原 優助教 に感謝致します。また, 本研究の一部は科研費若手 $(\mathrm{B})$ (21700486), 若手 $(A)$ (25709064) の助成を受けて推進さ れました。

\section{参 考 文 献}

1. A. Yamamoto, J. Biomed. Mater. Res., 39, 331 (1998).

2. P.L. Sanderson, Injury, 23, 29 (1992).

3. C. Robert, Clin. Orthop. Relat. Res., 388, 218 (2001).

4. E. Kobayashi, M. Ando, Y. Tsutsumi, H. Doi, T. Yoneyama, M. Kobayashi and T. Hanawa, Mater. Trans., 48, 301 (2007).

5. N. Nomura, Y. Tanaka, R. Kondo, H. Doi, Y. Tsutsumi and T. Hanawa, Mater. Trans., 502466 (2009).

6. J. Black, "Biological performance of materials" , 2nd Ed., p.400, Marcel Dekker (1992).

7. Y. Tanaka, E. Kobayashi, S. Hiromoto, K. Asami, H. Imai and T. Hanawa, J. Mater. Sci. Mater. Med., 18, 797 (2007).

8. Y. Takano, Y. Tsutsumi, K. Noda, H. Doi and T. Hanawa, Proc. JSCE Materials and Environments 2007, p.383, JSCE (2007).

9. Y. Takano, Y. Tsutsumi, H. Doi, N, Nomura, K. Noda and T. Hanawa, Proc. 55th Jpn. Conf. Materials and Environments, p.177, JSCE (2008).

(2014 年 1 月 10 日受理) 
要旨

擬似体液中における純 $\mathrm{Zr}$ と $\mathrm{Zr}$ 二元合金の腐食挙動を評価した。純 $\mathrm{Zr}$ の動電位アノード分極試験にお いて孔食発生がみられたが, 孔食電位は $316 \mathrm{~L}$ ステンレス鋼より大幅に高い值であった。十分な濃度で $\mathrm{Ti}, \mathrm{Nb}, \mathrm{Au}$ と Zr を合金化した試料では, 純 Zr より高い孔食電位を示したことから, これらの元素は耐 食性の向上に寄与することがわかった。一方，Cu との合金化では孔食電位が大幅に低下したことから， 耐食性の悪化につながることが明らかになった。これらの結果から, 純 Zr は十分な耐食性を有している が，塩化物環境で使用する合金の設計時には，十分な注意を要することがわかった.

キーワードジルコニウム，孔食，生体材料，合金化，擬似体液 